\title{
Difficulties in Potato Pest Control: The Case of Pyrethroids on Colorado Potato Beetle
}

\author{
Imola Molnar and Elena Rakosy-Tican *
}

check for updates

Citation: Molnar, I.; Rakosy-Tican, E. Difficulties in Potato Pest Control: The Case of Pyrethroids on Colorado Potato Beetle. Agronomy 2021, 11 , 1920. https://doi.org/10.3390/ agronomy11101920

Academic Editors: Jaime Carrasco and Francisco J. Gea

Received: 18 August 2021

Accepted: 22 September 2021

Published: 25 September 2021

Publisher's Note: MDPI stays neutral with regard to jurisdictional claims in published maps and institutional affiliations.

Copyright: (c) 2021 by the authors. Licensee MDPI, Basel, Switzerland. This article is an open access article distributed under the terms and conditions of the Creative Commons Attribution (CC BY) license (https:// creativecommons.org/licenses/by/ $4.0 /)$.
Plant Genetic Engineering Group, Department of Molecular Biology and Biotechnology, Faculty of Biology and Geology, Babeş-Bolyai University, Strada Mihail Kogălniceanu 1, 4000 Cluj-Napoca, Romania; imola.molnar@ubbcluj.ro

* Correspondence: arina5744@yahoo.com

\begin{abstract}
Colorado potato beetle (Leptinotarsa decemlineata, CPB) is considered one of the most persistent crop pests because it is highly adaptable and can rapidly develop insecticide resistance. Nowadays, this beetle is resistant to over 54 different insecticides. In the absence of competitive alternatives, the answer of farmers to the high degree of pest adaptability is to increase the number of pesticide treatments or apply chemicals with different modes of action. Such a strategy increases the risk of intoxication in non-target organisms and leads to environmental pollution, augmenting the carbon footprint. Furthermore, these strategies are also unsustainable and inefficient for pest management in the long-term. The time has thus come to reform existing agriculture practices, for which the implementation of an integrated pest management strategy would be a more feasible tool. Applying a sustainable pest management strategy is indispensable for a better understanding of the status and mechanisms of insecticide resistance. Effective pest management requires monitoring the resistance of pests and developing a well-programmed pesticide treatment to simultaneously reduce the insecticide selection pressure and environmental pollution. In this context, here we present a review on the difficulties of potato pest control using as a case study the resistance of $\mathrm{CPB}$ to pyrethroids.
\end{abstract}

Keywords: Colorado potato beetle; insecticide resistance; potato; pyrethroids

\section{Introduction}

Pesticides are natural or synthetic substances used to kill, deter or control undesirable organisms. The pesticides family includes herbicides, insecticides, fungicides and disinfectants for preventing the spread of bacteria or viruses [1]. The toxicity of pesticides is determined not only by the concentration of the substances but also by the exposure time [2]. The irresponsible use of these chemicals substantially increases our environmental footprint. Generally, small residues of synthetic pesticides can persist for a long time in the environment (soil, fresh or sea water, on the surface of vegetables or even inside the crops and derived products), which also increases the possibility of poisoning non-target organisms, including humans. Nevertheless, global food production will need to increase in order to feed the increasing population, which will drive an intensification of agricultural production and lead to an increased demand for agrochemicals [3].

Despite the extensive use of pesticides with various active ingredients, an estimated $34 \%$ of all potato crops are lost annually to insect pests. Major pathogens (Phytophthora infestans, Alternaria solani, Thanatephorus cucumeris), viruses (potato leafroll virus, potato virus Y) and animal pests (potato cyst nematodes, Colorado beetle, Phthorimaea operculella) are widely distributed, which can wreak havoc on potato fields if left uncontrolled. Without crop protection almost $75 \%$ of potato production would be lost $[4,5]$. 


\section{A Brief Historical Overview of Insecticide Use}

Botanical preparations (i.e., Dalmatian pyrethrum flowers, elderberry flowers, tobacco infusions) were the first substances used as insecticides by ancient people. The next major stage was the use of inorganic insecticides such as arsenic and boric acid, which offered only marginal control of insects. Starting in the middle of the 19th century, pest control with insecticides gained wider use. For example, Paris green (mixed copper acetoarsenite) was successfully used to control the Colorado potato beetle, Leptinotarsa decemlineata (Say), (CPB in many countries around the world. A step forward in the early 20th century was the discovery of synthetic organic insecticides, which opened new horizons in pest control [6]. In 1939, the insecticidal activity of dichlorodiphenyltrichloroethane (DDT) was discovered, and this substance led to the development of chlorinated compounds like lindane and hexachlorocyclohexane. These chlorinated insecticides dominated the market for nearly three decades, when another promising insecticide group was developed, the organophosphates (parathion, malathion and diazinon) [7]. In the middle of the 20th century, synthetic carbamates were introduced. The most widely used carbamates-carbaryl and aldicarb-are derivatives of physostigmine obtained from Calabar bean [8]. The success of pyrethroids started in the 1970s when permethrin and deltamethrin were discovered [9]. The main advantage of pyrethroids compared to other synthetic insecticides was the requirement of lower doses to achieve the expected potent effect. In the last decades, neonicotinoids (i.e., imidacloprid and dinotefuran) were developed, which are systemic insecticides and therefore used to treat seeds to provide plant protection against pests from germination until full development [9-11].

\section{Types of Insecticides Affecting Different Membrane Channels}

Nowadays, different classes of insecticides are available on the market, which have a wide range of mechanisms of action. This section only includes those insecticides that act directly or indirectly on different membrane channels. Understanding the various actions of insecticides on ion channels will be important when the cellular mechanisms and effects of pyrethroids are discussed. The other types of insecticides are equally important, but they are not closely related to the current topic. The newest information about the existing insecticide classes and their mode of action was recently published by the Insecticide Resistance Committee (IRAC) [12].

Ryanodine and synthetic diamides are ligands of ryanodine receptors (RyRs), which are members of the ligand-gated calcium channel family and are mainly located on the sarcoplasmic reticulum of muscle cells and the endoplasmic reticulum of neuronal cells $[13,14]$. Ryanoids and synthetic analogs induce cessation of feeding, lethargy, paralysis, and death. The molecular background of these symptoms is based on the prolonged activation of RyRs by ryanoids, which leads to an elevated level of cytoplasmic calcium. The increased concentration of $\mathrm{Ca}^{2+}$ in muscle cells induce sustained skeletal muscle contraction and paralysis, while in neurons induce cytotoxicity and altered neuronal activity (Figure 1) [13,15].

Neonicotinoids (e.g., imidacloprid, dinotefuran) represent a large group of insecticides that act selectively on the nicotine receptors of acetylcholine (nAChRs), which play a crucial role in synaptic transmission in the central nervous system of insects [7]. The nAChRs are activated through the binding of acetylcholine ( $\mathrm{ACh}$ ) neurotransmitters and are deactivated when the acetylcholinesterase enzyme $(\mathrm{AChE})$ rapidly hydrolyzes the ester linkage in acetylcholine. The same activation mechanism of nAChRs also occurs in the presence of neonicotinoids. Only the deactivation process is missing, because AChE cannot break down and inactivate these types of insecticides. This persistent activation leads to an overstimulation of the cholinergic synapses and results in hyperexcitation, convulsions, paralysis, and finally insect death (Figure 1) [16,17]. In the last decades, neonicotinoids were widely used chemicals to control undesirable organisms. Some studies pointed out that neonicotinoids can accumulate in the environment, which increases the risk of long-term intoxication [18]. In addition, it was confirmed that this group of insecticides represents a danger for honey and wild bees. Therefore a ban on outdoor use of several 
neonicotinoids (clothianidin, imidacloprid, thiamethoxam (2013) and thiacloprid (2020)) was implemented in European countries [17,19].

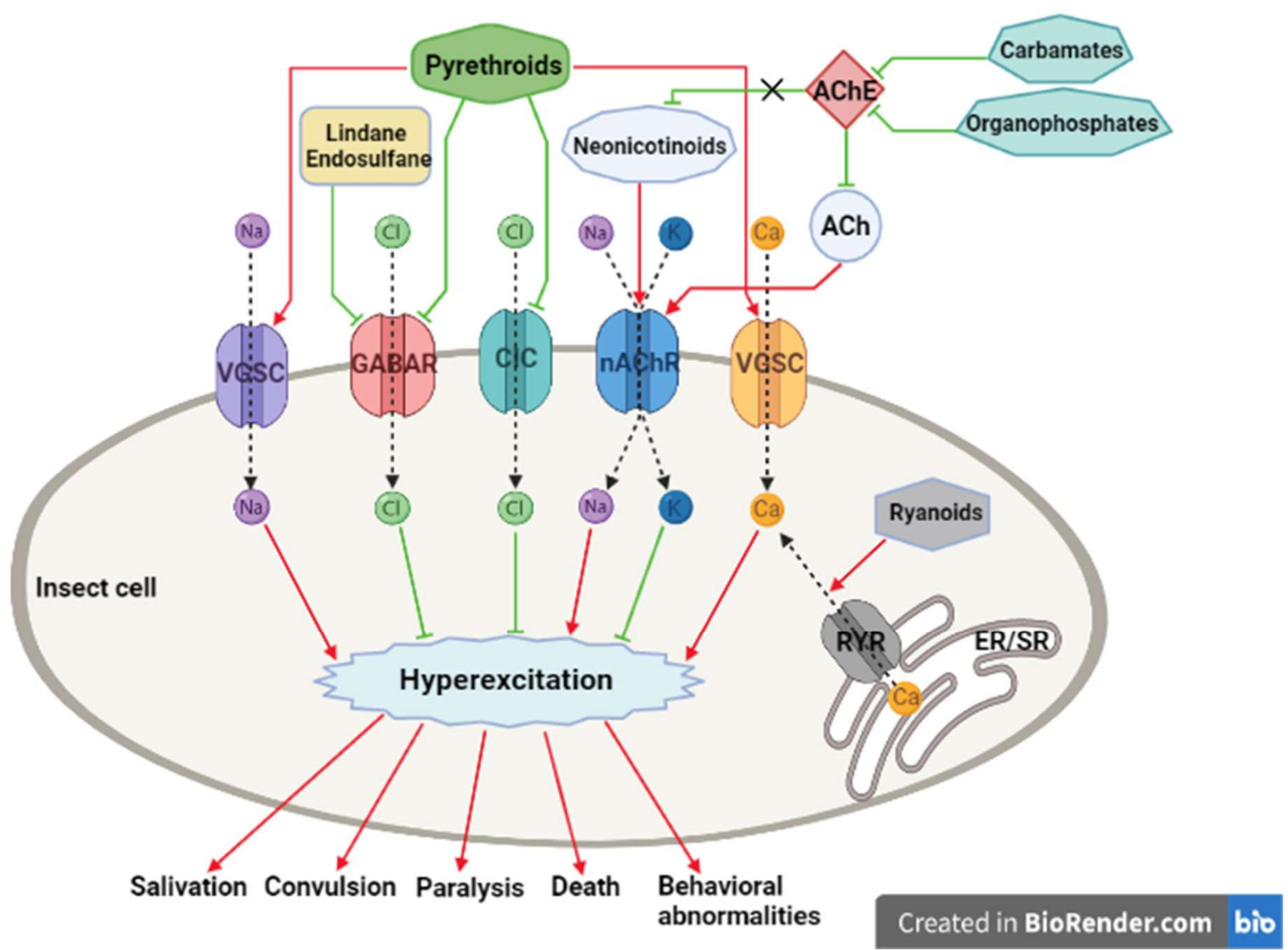

Figure 1. Molecular actions of different classes of insecticides on ion channels. In normal conditions, the alternation of activation and inhibition of ion channels are essential in neurotransmission. Any external factor which upsets this balance prevent the formation of normal membrane potentials, which leads to unconventional neurotransmission (e.g., hyperexcitation of cells). The induced irregular neurotransmission may produce different symptoms (e.g., convulsions, paralysis) and even lead to death. (Abbreviations: GABA $=\gamma$-aminobutyric acid, $\mathrm{Ach}=$ acetylcholine, $\mathrm{AChE}=$ acetylcholinesterase, $\mathrm{RyR}=$ Ryanodine receptor, VGSC = voltage-gated sodium channel, GABAR $=$ GABA receptor, $\mathrm{nAChR}=$ nicotinic acetylcholine receptor, $\mathrm{Na}=$ sodium ion, $\mathrm{Cl}$ = chloride ion, $\mathrm{K}$ = potassium ion, $\mathrm{Ca}=$ calcium ion).

The organophosphates (OPs) and carbamates are inhibitors of the acetylcholinesterase enzyme (AChE), which increase synaptic concentrations of acetylcholine leading to hyperexcitation of the CNS (Figure 1). The signs of intoxication of organophosphates include restlessness, hyperexcitability, tremors, convulsions, and paralysis. In mammals there is also a significant involvement of peripheral cholinergic systems in OP and carbamate poisoning, leading to the so-called Salivation, Lachrymation, Urination, Defecation, Gastrointestinal upset and Emesis (SLUDGE) syndrome [20].

The insecticides 4, $4^{\prime}$-diisothiocyano-2,2'-stilbenedisulfonic acid (DIDS), anthracene-9carboxylic acid, 5-nitro-2-(3-phenylpropylamino)benzoic acid (NPPB) and indanyloxyacetic acid (IAA-94) inhibit the current of the voltage-gated chloride channel (VGCC). These compounds function as dietary insecticides and present dose-dependent effects with low mammalian toxicity rates [21]. 
The lindane, endosulfan, isoxazoline, and metadiamide insecticides inhibit the proper functioning of the $\gamma$-aminobutyric acid (GABA) receptors, therefore, affect $\mathrm{Cl}^{-}$inflow (Figure 1) [22]. Only lindane and endosulfan are still in use, but they are also gradually being phased out due to their high mammalian toxicity and especially, their high dermal toxicity.

Both types of chloride channel blockers (VGCC-, GABA receptor-blockers) induce CNS hyperexcitability and convulsions not only in insects, but also in mammals [21,22].

All presented substances alter normal neurotransmission by modifying the functions of different ion channels. These insecticides often overstimulate the firing of excitatory neurons, which lead to hyperexcitation, or they achieve the same effect in a completely different way by blocking the inhibitory neurotransmission (Figure 1).

\subsection{Pyrethroids}

Pyrethroids are synthetic structural derivatives of insecticidal pyrethrins found in the pyrethrum extract of Chrysanthemum species and can be characterized by having a high degree of lipophilicity [23]. Pyrethroids belong to the fourth group of insecticides according to the WHO classification and include 42 substances [24]. Natural pyrethrins consist of six compounds: pyrethrin I and II, jasmolin I and II, and cinerin I and II. Pyrethrum extract is the most effective natural insecticide, but it is unstable in light and air, which decreases its effectiveness in crop protection. During the development of synthetic pyrethroids, the main goal was to modify the structure of pyrethrins to become more stable in lightning conditions, but do not decrease the potency and rapidity of insecticidal activity and/or have relatively low mammalian toxicity [25]. Pyrethroids can be classified into Type I or Type II groups, depending on the alcohol substituent in the molecule. The members of Type I group contain descyano-3-phenoxybenzyl or other alcohol chain moieties. The older Type I compounds without phenoxybenzyl alcohol (e.g., bioallethrin, tetramethrin) are relatively unstable in outdoor conditions. Therefore they were mainly used as household disinsectants for flying or crawling insects. The introduction of phenoxybenzyl (e.g., permethrin) or other halogenated alcohols (e.g., tefluthrin) improved the chemical stability of these compounds, which opened the possibility of applying pyrethroids in the field. The Type II pyrethroids contain $\alpha$-cyano-3-phenoxybenzyl alcohol, which yields a 3-6-fold increase in its insecticidal performance compared to the cognate non-cyano analogs (Figure 2) [26].

\begin{tabular}{|c|c|c|}
\hline $\begin{array}{c}\text { Natural insecticide } \\
\text { (Pyrethrin I) }\end{array}$ & $\begin{array}{c}\text { Type I pyrethroid } \\
\text { (Permethrin) }\end{array}$ \\
(Cypermethrin)
\end{tabular}

Figure 2. Chemical structure of pyrethroid insecticides (From left to right: pyrethrin I, permethrin, cypermethrin). The introduction of phenoxybenzyl alcohol moiety into the chemical structure of natural pyrethrins increases the stability of the Type I pyrethroids. All Type II pyrethroids have a cyanide group.

The chemical structure of pyrethroids is highly flexible with many attainable geometries. Therefore, they can be used as mixtures of active isomers (e.g., allethrin) or as single isomers (deltamethrin and esfenvalerate) [27]. 


\subsection{Toxication Symptoms of Pyrethroids}

The new generation of synthetic pyrethroids was selected to be less sensitive to photodegradation, but despite this property, in general, pyrethroids are still highly photolabile which greatly reduces their potential for mammalian poisoning. They proved to be 2250 times more toxic to insects than vertebrates due to the smaller size of insects, lower body temperature and more sensitive sodium channels [28]. A single high dose of Type I pyrethroids could cause hyperexcitability and convulsions in insects and whole-body tremor, furthermore aggression, convulsive twitching, named as $\mathrm{T}$ syndrome in mammals. Whereas Type II pyrethroids induce ataxia and incoordination in insects, while in mammals, they produce choreoathetosis, salivation, clonic seizures named as CS syndrome [11].

Pyrethroids may enter the body through skin contact, inhalation and food or water ingestion [29]. Furthermore, pyrethroids are toxic to aquatic animals, e.g., shellfish (crayfish, lobster), and fish (Danio rerio Hamilton-Buchanan, carp and rainbow trout), affecting not only the ion channels in neuronal membranes, but also in the mitochondrial membranes [30-34]. All pyrethroids are rapidly metabolized in mammals and their metabolites are almost completely excreted within several days, except for the cyano moiety. Therefore, tissue residues in mammals are relatively low $[10,35]$. The major metabolic reactions of pyrethroids are the following: oxidation of methyl groups and aromatic rings; hydrolysis of the ester linkage; and several types of conjugation reactions, which are mediated by carboxylesterases and members of cytochrome P450 [36].

Even though pyrethroids are relatively safe insecticides rapidly metabolized in mammals, chronic exposure or a high single dosage of pyrethroids can result in intoxication with different severity of symptoms, or even death [37]. After the consumption of different types of food: pasta, rice, whole meal bread, and fruits from sprayed areas, the metabolites of pyrethroids were detected in the urine [38,39]. In mammals, age-related sensitivity was observed to pyrethroids, for example: deltamethrin was more toxic to young rats than to adults, or cypermethrin proved to be more toxic in younger individuals [40]. Furthermore, due to the lipophilicity feature of pyrethroids, they can easily pass through the blood-brain barrier and at high concentrations they can also have neurotoxic effects [41,42]. Developmental pyrethroid exposure results in alterations of the nervous system structure and functions, which manifests in deficits of motor coordination, learning, and memory performance. Long-term exposure of children to permethrin caused an increase in the number of permethrin metabolites in the urine, as well as behavioral changes, in particular an increase of aggressive behaviors and sleep disorders [43]. Furthermore, children were characterized by impaired memory, poorer verbal abilities and decreased intelligence scores [44]. Many other side effects of permethrin exposure were observed: household usage of permethrin is often associated with allergies and asthma, especially in children. Skolarczyk et al. [45] demonstrated an immunosuppressive effect of pyrethroids in the case of children. Furthermore, permethrin metabolites were detected in breast milk from women in Brazil, Colombia and Spain [46]. Daily exposure to pyrethroids leads to neuronal cell loss in various brain regions, which is a result of increased production of reactive oxygen species, increased expression of pro-apoptotic genes: p53 and Bax, and decreased expression of anti-apoptotic Bcl-2 [40,47]. Nonetheless, the U.S. Centers for Disease Control recommends the use of pyrethroid repellents as safe substances to protect pregnant women against Zika infection [48,49]. 


\section{Mechanism of Action of Pyrethroids}

\subsection{Pyrethroids Effects on Voltage-Gated Sodium Channels (VGSCS)}

Pyrethroids are predominately absorbed through the insect cuticle, and after reaching the nervous system, disrupt the membrane potential and neurotransmission, causing knockdown and subsequently death. Under normal conditions, nerve impulses (action potential) consist of arranged ion movements through specific ion channels. The action potential has three distinct phases: in the initial step, nerve impulses open the VGSCs and $\mathrm{Na}^{+}$ions flow into the cells leading to membrane depolarization (positive wave), followed by a repolarization wave from the efflux of $\mathrm{K}^{+}$ions when the value of the membrane potential becomes negative again; finally comes the restoration of the resting potential by the active transport of $\mathrm{Na}^{+} / \mathrm{K}^{+}$pump. The generated action potential moves towards the axon until reaching the nerve terminal, which induces different neurotransmitters [50].

VGSCs consist of two subunits: $\alpha$ subunit, which forms the pore and an auxiliary subunit. The $\alpha$ subunit contains six transmembrane segments (S1-S6), where S4, S5 and $\mathrm{S} 6$ segments form the channel pore and confer selectivity for $\mathrm{Na}^{+}$. The $\mathrm{S} 6$ segment is involved in the activation gating of the channel allowing $\mathrm{Na}^{+}$inflow. During the resting potential and repolarization phase of an action potential, the pores of VGSCs are closed [51,52]. In insects, a single gene encodes the VGSC $\alpha$ subunit, while mammals have nine distinct pore-forming $\alpha$ subunit genes. Sodium channel isoforms expressed in various mammalian tissues exhibit different sensitivity to pyrethroids. Mutations in the sodium channel could induce pyrethroid resistance. This phenomenon was observed in case of several model species and insect pests (Drosophila melanogaster, Xenopus laevis and Colorado potato beetle). The majority of resistance-associated mutations are found in the intracellular linkers between S4, S5 or within transmembrane helices S5 and S6. Genetic mapping of pyrethroid resistance genes in insects clarified the pyrethroid-binding site on VGSC that was localized between the transmembrane helices S4 and S5 segments [53].

Pyrethroids delay VGSC inactivation resulting in a prolonged $\mathrm{Na}^{+}$current, which leads to hyperexcitation of neurons. In general, Type II compounds delay the inactivation of sodium channels substantially longer than Type I compounds do, which induce multiple spike discharges in neurons [54]. Type II pyrethroids depolarize the ax on membrane potential, which reduces the amplitude of the action potential and eventually leads to the loss of electrical excitability. All these effects occur mainly because pyrethroids extend the duration of the $\mathrm{Na}^{+}$flowing through sodium channels by slowing down or preventing their inactivation [54]. Moreover, the prolonged $\mathrm{Na}^{+}$flow increases the release of neurotransmitters from presynaptic nerve terminals. The different effects of Type I and Type II pyrethroids are due to the variance in the duration of modified sodium currents: Type I compounds produce long action potentials (burst discharges) as a result of a single stimulus with little or no effect on the resting potential, while Type II compounds do not induce repetitive discharges, they cause a use-dependent blockage of the action potential coupled with depolarization of the resting potential [11].

Pyrethroid insecticides primarily target VGSCs, but also affect the function of other voltage-gated channels such as calcium and chloride channels and the binding of pyrethroids to GABA receptors was also observed. The effects of pyrethroids on these alternative targets have been demonstrated mainly in mammals, but recent studies showed that these membrane proteins are also targeted by pyrethroids in insects [53,55-57].

\subsection{Alternative Targets of Pyrethroids}

Several studies have demonstrated that pyrethroids influence neuronal voltage-gated calcium channels (VGCCs) in the same concentration range observed in the case of neuronal VGSCs (Figure 1). Allethrin (Type I) blocked recombinant rat L-, P/Q- and T-type VGCCs at a concentration like that required for the VGSC channels in human embryonic kidney cells [58-60]. Direct effects of pyrethroids on VGCCs explain the enhanced neurotransmitter release in the CNS, resulting in CS syndrome of intoxication [61]. In insects, pyrethroids also influence the function of VGCCs. Wang et al. [53] demonstrated that deltamethrin 
might act on T-type VGCCs in brain cells of honeybees and result in behavioral abnormalities including swarming, feeding, learning, and acquisition. VGCCs are also alternative targets for Type II pyrethroids. Deltamethrin induces concentration-dependent blockage of chloride channels in muscle cells, as well as in peripheral and CNS neurons. Pyrethroids inhibit the $\mathrm{Cl}^{-}$permeability leading to increased muscle membrane resistance and salivation, which are symptoms of CS syndrome (Figure 1) [62,63]. Jenson [56] proved for the first time that Type II pyrethroid block chloride channels in Spodoptera frugiperda and Anopheles gambiae insect cells. Moreover, Type II pyrethroids bind to and block GABA receptors in mammalian brain preparations. However, higher concentrations are needed than in case of sodium channels. The blockage of GABA receptors is an indirect neuroexcitatory effect involving the removal of inhibitory neuronal input, leading to convulsions [11,53]. Furthermore, pyrethroids could directly act on GABA receptors and reduce GABA-mediated responses in insects. The blocking effect of deltamethrin on GABA receptors was observed in Anopheles gambiae and Apis mellifera (Figure 1) [55,64].

\section{Insecticide Resistance-The Case of Colorado Potato Beetle}

The CPB has been considered as a model for pest mismanagement, because it is highly adaptable and can rapidly develop insecticide resistance. Due to its feeding, mating habits and great adaptability, CPB has developed this "superpower". CPB is the most devastating defoliator of cultivated potatoes, but also may cause significant damage to tomatoes and eggplants [65,66]. Nowadays, the CPB distribution area is around 16 million $\mathrm{km}^{2}$ in North America, Europe and Asia, which is extremely large compared to its initial estimated $5000 \mathrm{~km}^{2}$ living territory $[67,68]$.

In continental climates, with colder winters, CPB adults enter diapause, which is induced by a short-day photoperiod, falling temperature, decrease of forage quality (yellowed leaves) and pass the wintertime in the soil [69]. In these areas, CPB generally brings up two generations per year, but in mild climate zones, three or even four generations may grow up [70]. During the spring or early summer, adult beetles colonize potato fields, they are attracted to volatile compounds of the Solanum species and immediately start to reproduce [71,72]. CPBs have high fecundity: female beetles may lay up to 800 eggs in their life [67]. The life cycle of CPB involves seven life stages (egg-4 larval stages-pupae-adult), larvae undergo metamorphosis to achieve adult form. Pupation occurs in the soil, and adults emerge one week later, depending on temperature [68]. Larvae and adults consume potato leaves and are especially voracious. Due to their mating and destructive feeding habits, they can completely destroy potato fields, if left uncontrolled [68]. Despite the relatively young evolutionary age of $\mathrm{CPB}$, they possess a high intraspecific polymorphism, which provides a broad range of ecological plasticity and adaptability to different biotic and abiotic factors $[68,73]$. Transposable elements, which comprise at least $17 \%$ of the CPB genome and high levels of nucleotide diversity in this pest population, facilitate rapid evolutionary changes [74].

Defoliation of potato plants by the CPB can significantly decrease tuber production [75]. A loss of more than $75 \%$ of the foliage can cause a total crop loss [76]. Several important potato producing countries, such as Russia, Ukraine, Poland and others in Eastern Europe, have reported high yield losses due to the CPB invasion [77].

For over 125 years management of CPB has been mainly based on chemical control. In Europe, potato crops are treated with insecticides against CPB 3-4 times per year to achieve the expected yield. Increasing the dosage provides only short-term relief but greatly contributes to the development of resistance. Nowadays, the control of CPB has become difficult due to the rapid evolution of its resistance to most insecticides through both, cross-resistance and multiple resistance to different compounds. Unsuccessful sublethal pyrethroid control of CPB leads to undesired side effects: it has a positive fitness effect over generations in $\mathrm{CPB}$, by increasing the survival rate of the insect and reaching higher body mass, which is known to facilitate the population growth and invasion success [78]. Moreover, the development of resistance to insecticides significantly increases 
potato production costs, it contaminates the environment and disturbs the equilibrium of agro-ecosystems [70,79].

High predisposition to resistance development in CPB is caused by several distinct factors: co-evolution of the $\mathrm{CPB}$ and Solanaceae species promoted the development of the enhanced detoxifying ability of beetles to tolerate high concentrations of toxic glycoalkaloids which is a specific repellent chemical of the Solanaceae species. Similarly, the high fecundity rate increases the appearance of random mutations in $\mathrm{CPB}$ populations, while a large number of laid eggs by a resistant beetle also ensures successful integration of the new trait. Furthermore, the narrow host range of beetles reduces the possibility of the existence of undisturbed refugees, where susceptible genotypes may escape exposure to chemicals. Last but not least, excessive pest control with different pesticides has been a major concern due to the repeated development of resistance in the CPB population $[79,80]$.

Known mechanisms of $\mathrm{CPB}$ resistance to insecticides include mutations in genes encoding target receptors or enzymes (e.g., VGSCs, AChE), enhanced metabolism involving esterases, carboxylesterases, and monooxygenases, as well as reduced insecticide penetration and increased excretion (Figure 3) [67].

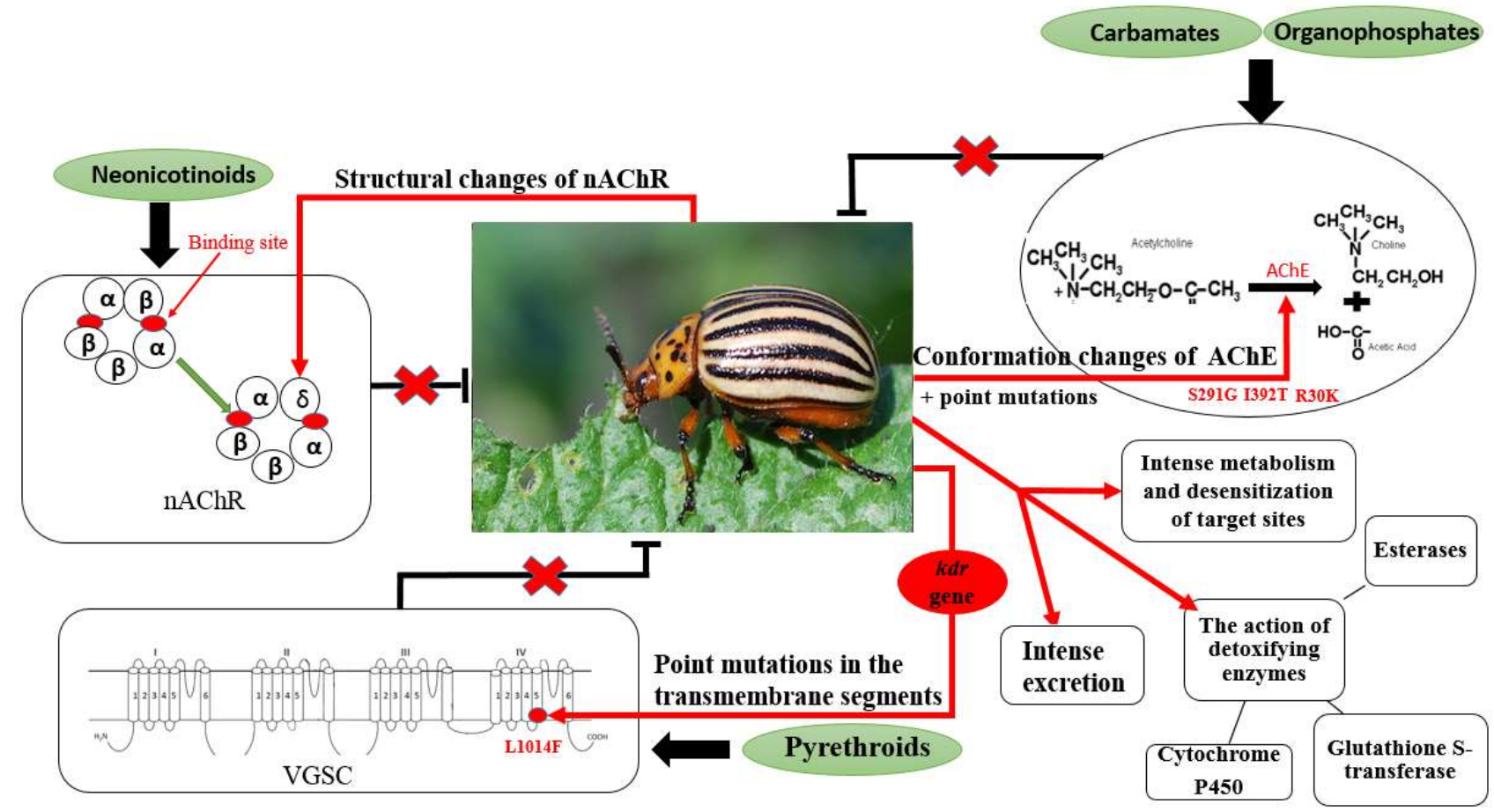

Figure 3. $\mathrm{CPB}$ resistance mechanisms to the organophosphate, carbamate, neonicotinoid and pyrethroid insecticides. Black arrows indicate the mode of action of different insecticides. Red arrows indicate the developed CPB resistance mechanisms, which prevent the harmful effects of insecticides (red X).

Resistance mechanisms may be highly diverse, even within a relatively narrow geographical area and between the life stages of the beetle [66,81]. The first recorded case of the resistance of this pest to a synthetic organic compound was the failure of DDT in 1952. Since then, CPB has developed resistance to over 54 different insecticides including organophosphates, pyrethroids, neonicotinoids and others. [79,82,83]. Over 300 documented cases of insecticide resistance are listed in the literature coming from Asia, Europe, and North America [84].

In 1965, an endosulfan (organochlorine insecticide)-resistant CPB population was recorded for the first time [5]. The CPB resistance mechanism involved in defense against endosulfan is mainly metabolic, by increasing the enzymatic activity and increasing the number of enzymes: esterases, monooxygenases, and glutathione-S-transferase (Figure 3) [85]. 
The Colorado potato beetle's resistance to azinphosmethyl (an organophosphate) and carbofuran (a carbamate) were observed as early as the late 1970s [5]. This resistance is associated with a point mutation in AChE, a substitution of adenine with guanine at position 980 in the AChE gene, which leads to the change of serine to glycine (S291G) [86]. Furthermore, two other AChE mutations were identified in CPB, which were associated with resistance to these insecticides, R30K (replacement of the amino acid arginine with lysine) and I392T (replacement of isoleucine with threonine) [87]. The S291G mutation leads to conformational changes at the $\alpha$-helix level in AChE that affect the binding sites for the insecticides in this enzyme (Figure 3) [86,88].

The intensive use of pyrethroids in controlling pests and disease vectors has been one of the main factors contributing to the development of pyrethroid-resistance among insects, which nowadays has grown into a global problem. One of the major mechanisms of pyrethroid-resistance, which reduces neuronal sensitivity to this class of insecticides, is known as knockdown resistance $(k d r)$ of VGSCs. This mutation was initially found in Musca domestica [89], but soon in many other insects such as Blatella germanica [90,91], Anopheles gambiae [92] and Myzus persicae [93]. Nowadays, the $k d r$ mutation has been documented globally in most arthropod pests and disease vectors [51]. The $k d r$ mutation consists of substituting leucine for phenylalanine at position 1014 (L1014F), which confers resistance by reducing the binding of pyrethroids to sodium channels.

The $k d r$ mutation has been identified as the main mechanism of resistance to pyrethroid insecticides in CPB (Figure 3) [82]. The $k d r$ mutation shows an incompletely recessive inheritance in the $\mathrm{CPB}$ population [78,82]. In Europe, pyrethroid resistance due to $k d r$ was detected in CPB field populations in Bulgaria, Czech Republic, Germany, and Serbia [78,81,86,94,95]. In addition to L1014F, two more target site mutations (T929I, T929N) were described in the sodium channel, which confer a super- $k d r$-like phenotype in the Bulgarian CPB population (Figure 4) [95]. Co-occurrence of more than one resistanceassociated mutation drastically reduces the VGSCs sensitivity to pyrethroids, compared to single mutations.

I.

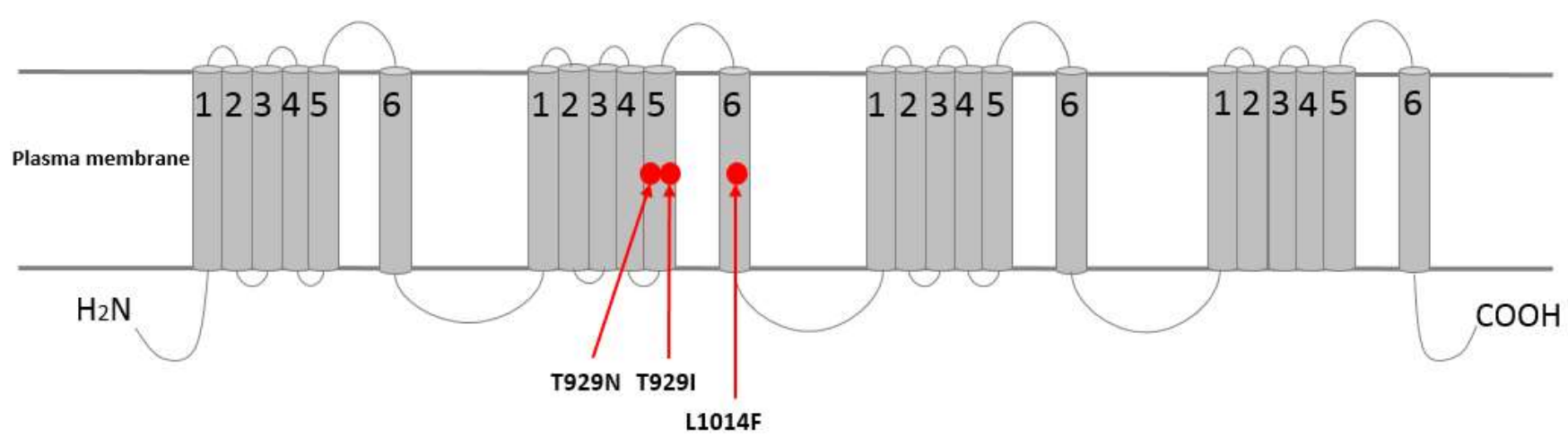

Figure 4. Identified mutations in the voltage-gated sodium channel in Colorado potato beetle populations that are associated with pyrethroid resistance (adapted from Rinkevich et al. [51]). The sodium channel protein contains four homologous repeats (I-IV), each part has six transmembrane segments (S1-S6). The red circle mutations were identified in pyrethroid resistant CPB: L1014F, T929I and T929N.

Oxidative metabolism participation in pyrethroid resistance is also well documented in the CPB population [94,96]. Resistant beetles detoxify the toxin (insecticide) faster than susceptible ones, or quickly rid their bodies of the toxic molecules. Resistant populations possess higher levels or more efficient forms of these detoxifying enzymes [67,94]. 
In the USA, several CPB populations are already resistant to pyrethroids, while in Europe, even though the pest control with pyrethroids is still effective, reduced susceptibility of pests to this chemical has also been observed $[81,86,94]$.

Since pyrethroid resistance evolved in CPB populations, neonicotinoid insecticides have been the cornerstone of CPB pest management in cultivated potatoes. However, the widespread use of neonicotinoids in the last decades has now led to the development of neonicotinoid-resistant $\mathrm{CPB}$ populations [82]. Nicotinoid resistance of CPB is due to overexpression of genes encoding detoxifying enzymes: cytochrome P450, glutathione S-transferase, UDP-glycosyltransferase, and xenobiotic transporters, i.e., ATP-binding cassette $(\mathrm{ABC})$ transporter, which participates in the excretion process of metabolized insecticides [97,98]. Furthermore, other mechanisms are involved in CPB resistance to neonicotinoids: mutations in the ACh receptor [99], reduced absorption and penetration of insecticides, increased activity of carboxylesterases and monooxygenases (Figure 3) [79].

The increased number of resistant CPB populations has a substantial impact on potato cultivation, undermining the effective production of this crop every year. With the persistent resistance occurrence in the $\mathrm{CPB}$ populations and the large impact of this pest on the potato industry, research in these areas could help in the development of better pest management strategies (integrated pest management-IPM), which have to focus on: (1) understanding the status and mechanisms of insecticide resistance by monitoring the resistance of local CPB populations; (2) overcoming or delaying resistance to existing insecticides by using well-established insecticide treatment plans (well-programmed pesticide treatment, combination of effective pesticides by omitting chemicals to which local CPB population is resistant) and (3) preventing the development of resistance to new pesticides by reducing the insecticide selection pressure with parallel application of other strategies than the chemical control (e.g., crop rotation, plantation of sensitive trap plants or resistant potato cultivars, treatments with bio-insecticides).

\section{The Numbers behind Potato Cultivation and Insecticide Use}

Chemical pest control was already preferred in the last century and it is still the predominant type of pest control. In case of $\mathrm{CPB}$, insecticides are the most important control measure on commercial potato farms. However, recent concern about the harmful effect of chemical pesticides on growers, consumers and the environment has encouraged scientists to consider alternative, safer and more effective control agents $[65,66]$. Furthermore, in 2009 the European Commission of the European Parliament proposed a plan to transform the European Union's agricultural system to a more sustainable and safer from health perspectives [100]. According to the plan, the main task is to reduce the risks and impacts of the excessive use of pesticides (the target is a reduction of $50 \%$ in the next decade), in addition, promote the use of alternative techniques (e.g., biological, mechanical control) and compliance with the principles of integrated pest management (IPM) [100]. Nonetheless, insecticide sales significantly increased in recent years in around $60 \%$ of the member states of the European countries (Figure 5) [101].

Germany, Italy and Spain are the top insecticide users from the European countries, while France, Ukraine and Romania use most of pyrethroids for pest control (Figure 6) [102]

France is the list leader in insecticides usage for potato production, followed by Netherland and Romania (Figure 7a) [102]. The first two countries are the main potato producers in terms of yield, while Romania occupies only 32nd place in the list based on statistics from the 2017-2019 period (Figure 7b) [102]. 


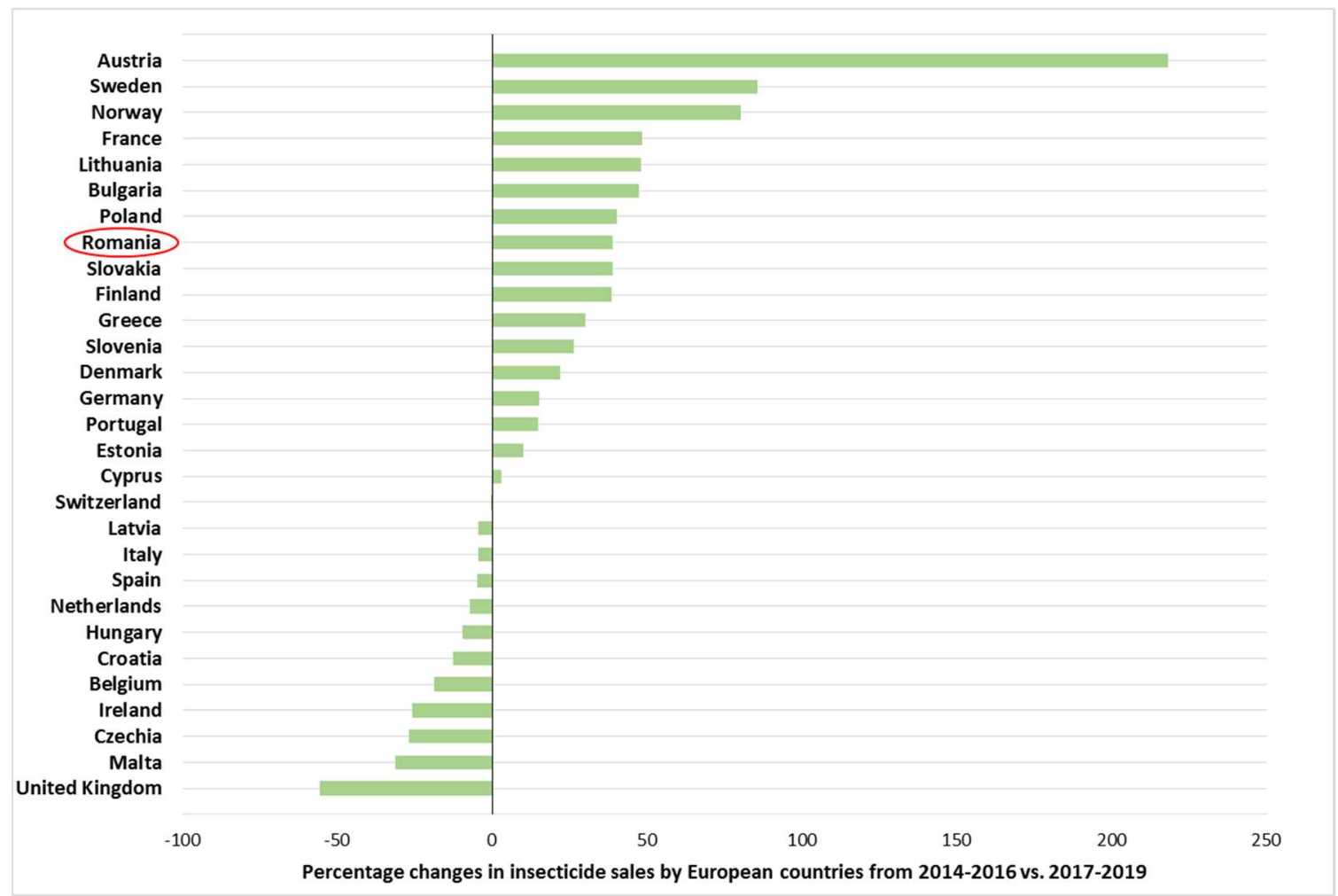

Figure 5. Percentage changes in insecticide sales by European countries from 2014-2016 vs. 2017-2019 (the presented graphic is based on data obtained from EUROSTAT database [101]).

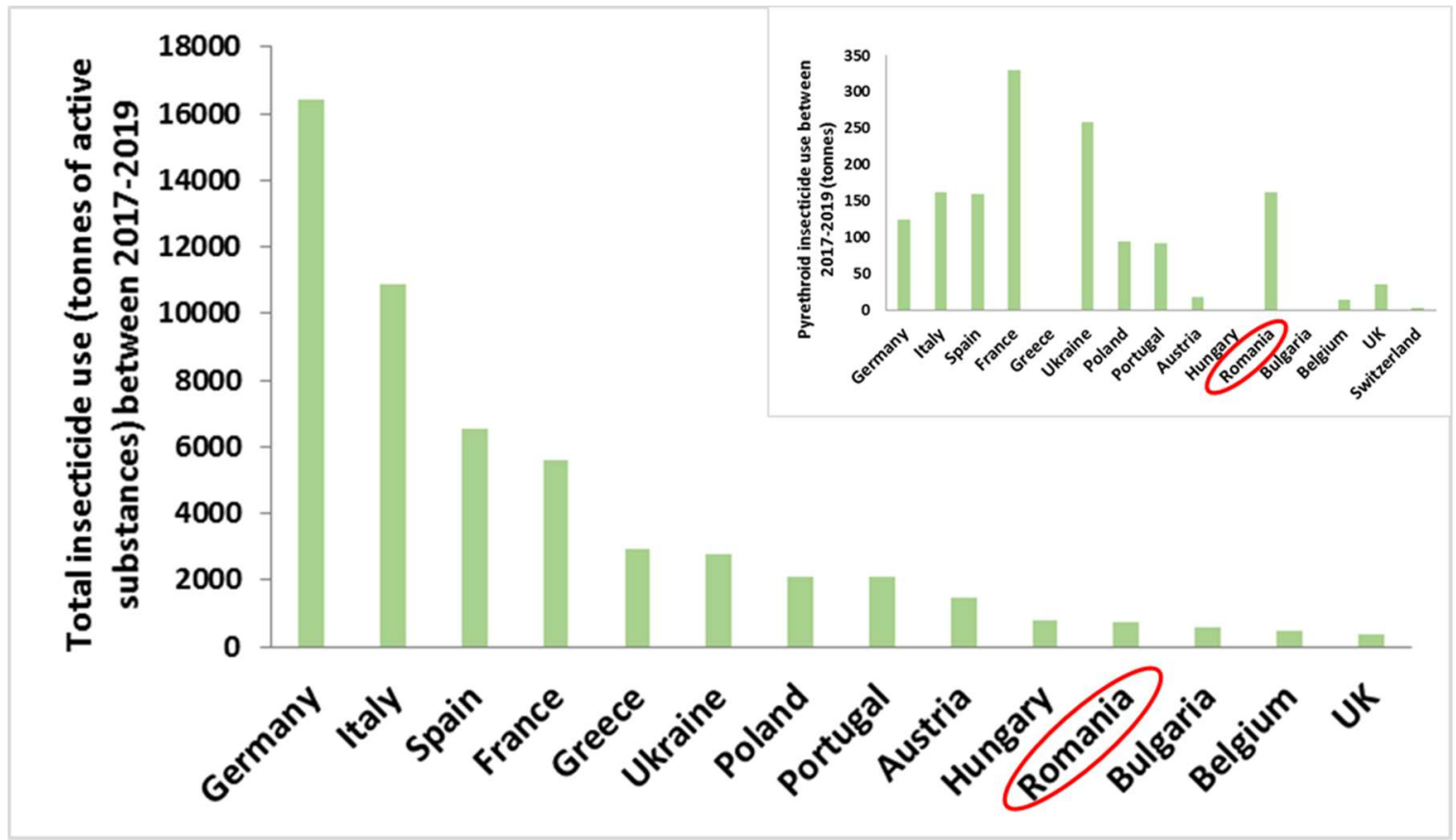

Figure 6. The European countries that used the most insecticides (total insecticide use in tonnes), between 2017 and 2019. The smaller right-sided graphic describes exclusively the pyrethroid use in these countries (the presented graphics are based on data obtained from FAOSTAT database [102]). 


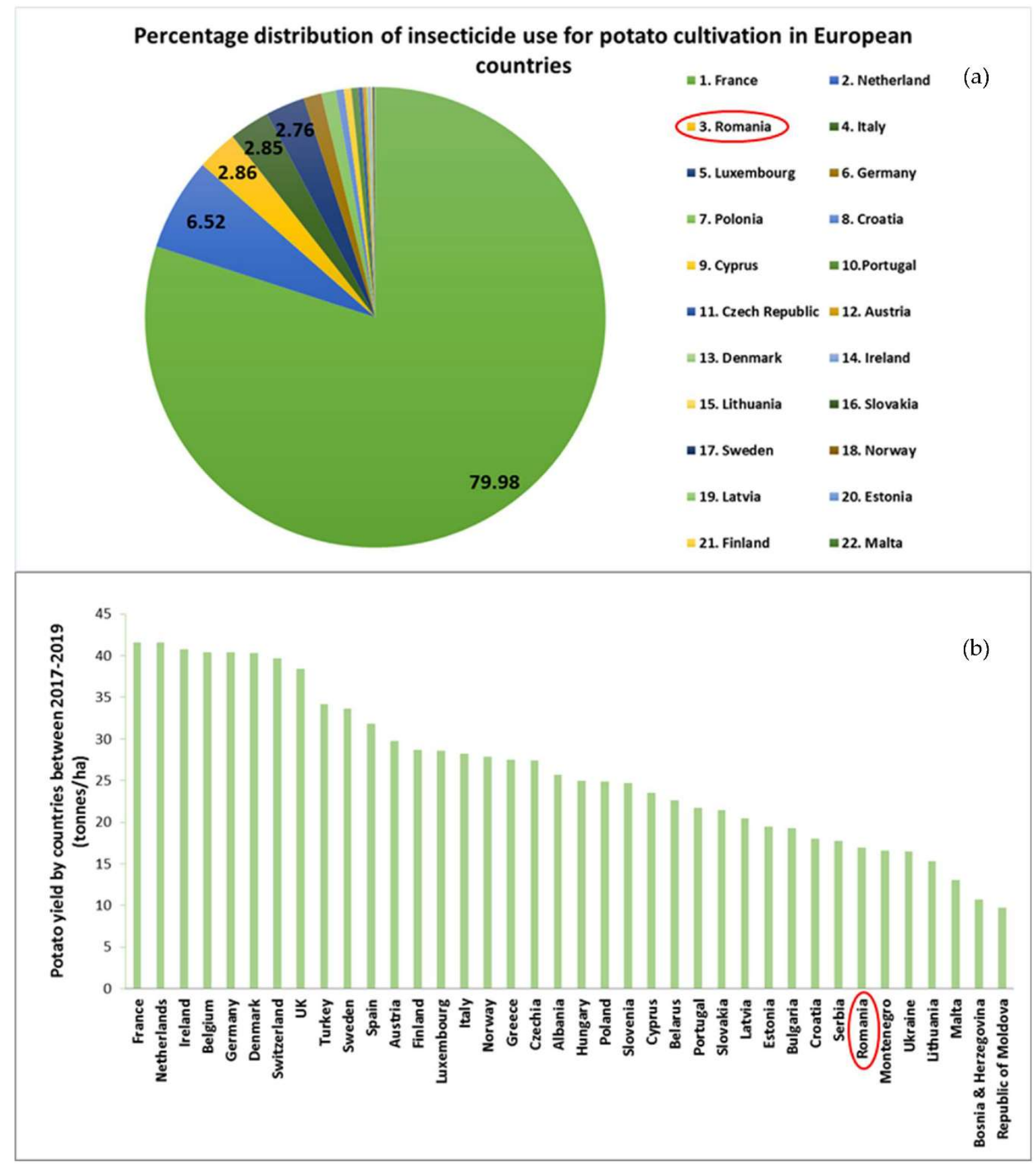

Figure 7. (a). Percentage distribution of insecticide use for potato cultivation in European countries (statistics for the last 10 years) (b). Potato yield by countries between 2017 and 2019 (tonnes/ha) (the presented graphics are based on data obtained from FAOSTAT database [102]).

\section{Perspectives to Reduce Insecticide Use}

Nowadays, there is an increasing awareness of the side effects of insecticides and researchers are looking for a more eco-friendly and sustainable solution to combat insect pests such as CPB. Strategies that meet the abovementioned criteria could be indirect and direct alternative control methods. Indirect alternative control methods are crop rotation [103], straw mulch [104], trap cropping [105] or selection of plant varieties [106]. Among all of them, crop rotation and selection of plant varieties are the most powerful in $\mathrm{CPB}$ control, but crop rotation alone is not effective enough, only slowing down $\mathrm{CPB}$ population buildups. On the other hand, there are only a few cultivars, which have some 
degree of resistance to CPB (e.g., cv. Dakota Diamond) [107,108]. Direct alternative methods to control CPB include behavioral interference methods [109], physical and mechanical control: bug vacuum [110], thermal pest control [111], use of natural enemies [112,113], use of the plant extracts and botanical insecticides [108]. Natural compounds and/or natural enemies are especially used in organic agriculture, but there is a growing interest in conventional agriculture. In Europe, there are only a few natural antagonists or parasitoids of the CPB beetle, and only a few studies are investigating the antibiosis effects of these bioinsecticides on $\mathrm{CPB}$, therefore the beetle-killing and or beetle-suppressing efficacy of these compounds needs to be further studied [114,115]. Pterostichus melanarius Illiger $[11,116]$ and Chrysoperla carnea Stephens [109] were found feeding on L. decemlineata. Two Tachinidae parasitic flies, Myiopharus aberrans L. and M. doryphorae Riley were found to parasitize L. decemlineata with relative success $[117,118]$. The disadvantages of using predators are multilayered. First of all, the newly introduced predator species can have an unknown effect on the global ecosystem, furthermore, their maintenance and production in adequate quantities are expensive and last but not least for releasing the predators, the purchase of additional equipment (mechanical distributors) is required [119]. Additionally some field studies suggest that natural enemies have a minimal effect [120-122].

Several species of Bacillus, including B. pumilus L., B. cereus, B. megaterium de Bary [123], and $B$. thuringiensis Berliner $(B t)[113,124,125]$, were found to increase L. decemlineata mortality. $B t$ toxin produced by these microorganisms is only effective if it is ingested. Field experiments demonstrate that spraying $B t$ is most successful against newly hatched $C P B$ larvae, so it should be used in the fields around this time [126,127].

Furthermore, biotechnological tools can be used, such as somatic hybridization, RNA interference (RNAi) [5,128], or CRISPR-Cas [129], to induce host plant resistance against $\mathrm{CPB}$ or $\mathrm{CPB}$ control. Among the wild potato relatives, several are described as resistant species for CPB attack through different mechanisms like special glycoalkaloids such as leptine I and II synthesized mainly in the leaves of Solanum chacoense or the tomatine present in some wild potato species and glandular trichomes mainly with repellent effect on the beetle. Some of the wild relatives of potato, which proved resistant are: S. bertaulthii, S. tarijense, S. neocardenasii, S. chacoense and S.bulbocastanum [77,130-132]. The differences in ploidy levels between cultivated potato $(4 \mathrm{x})$ and wild Solanum species (mainly $2 \mathrm{x}$ ) make it difficult to transfer the valuable resistance genes into cultivated potato germplasm using classical hybridization. One way for transferring multiple resistance genes from wild Solanum species is somatic hybridization via protoplast electrofusion. The advantages of this biotechnological approach are: (i) hybridization of sexually incompatible but related species that is impossible or difficult to realize using classical methods, (ii) the transfer of polygenes involved in resistance and/or multiple resistance traits, (iii) the somatic hybrid plants obtained through this technology are not considered as GMO in Europe (directive 2001/18/EC- annex 1B) [133]. Several studies demonstrate the possibility of transfer of the CPB resistance genes from wild relatives (S. tarnii, S. cardiophyllum and S. chacoense) to somatic hybrids and back-cross progenies (BCs) [134-137]. During the development and selection of new CPB resistant host plants, there is the chance to learn more about actionmechanisms of different metabolites involved in the plant defense. This could contribute to the discovery of novel, eco-friendly ways to combat this voracious pest. For example, the application of molecular markers for the detection of leptins [136] and the discovery of new quantitative trait locus (QTL) markers, which correlate with glandular trichomes excretory functions, would pave the way for marker-assisted introgression breeding. It is likely that there are still other factors which are involved in CPB resistance. However, these action-mechanisms are yet to be discovered and hopefully can also be used in the development of host plant resistance.

Moreover, it would be necessary to establish a uniform statistical follow-up system in all European countries in order to correctly estimate the situation of pesticide use, to accurately monitor the risk of pesticides. According to the present situation, the countries should report statistics on the agricultural use of pesticides for selected crops after every 
5 years and these reports are not uniform, detailed and unfortunately appropriately upgraded. The EU's executive organization aims to regulate pesticides statistics until 2023 in order to overcome such data gaps [100].

Furthermore, a better communication with farmers would improve the success of the implementation of integrated pest management (IPM) strategies. In many countries, such as Romania, farmers have little knowledge about biological and environmental issues concerning CPB. They have only one tool in their pocket to protect their potato plantations against this voracious pest, which is nothing else than the insecticides. Therefore, there is an urgent need to develop a local specific IPM strategy and to make it available and well-explained to farmers in order to improve the integration in cultural practices of the new, more eco-friendly strategies. For example: by using a well-programmed manner to apply only the effective insecticides, which could be selected based on monitoring of insecticide resistance of local CPB populations, the number of insecticide treatments could be substantially reduced. Other strategies would be the plantation of resistant potato cultivars or very sensitive genotypes as trap plants and the application of bio-insecticides; moreover, the use of natural enemies should reduce the monopoly of chemical insecticides.

\section{Conclusions}

Insects have a huge negative impact on potato and other crop yield and there is an urgent need for alternative, innovative but also scientifically sound strategies to combat them in a more environmental-friendly way, keeping in mind the permanent reduction of carbon footprint and development of sustainable methods to fight pests.

Author Contributions: Conceptualization I.M. and E.R.-T., writing the review I.M., correcting E.R.-T., both authors participated to and accepted the publication. All authors have read and agreed to the published version of the manuscript.

Funding: Babes-Bolyai University Young Researcher Grants 2019-2020 (GTC-2020).

Institutional Review Board Statement: Not applicable.

Informed Consent Statement: Not applicable.

Data Availability Statement: Not applicable.

Acknowledgments: I.M. was supported by funds from the Babes-Bolyai University Young Researcher Grants 2019-2020 (GTC-2020).

Conflicts of Interest: The authors claim no conflict of interest.

\section{References}

1. Dobrzanski, Z.; Buszewski, B.; Opalinski, S.; Kolacz, R.; Koziel, J.A. Xenobiotics, toxic compounds, mutagens and carcinogens substances. Classification and regulatory challenges. Chem. Ind. 2017, 96, 76-84.

2. Tennekes, H.A. The importance of dose-time-response relationships for hazard identification and limitation of animal experiments. Open Acc. J. Toxicol. 2017, 1, 555572. [CrossRef]

3. European Environment-State and Outlook 2015: Assessment of Global Megatrends, European Environment Agency. Available online: https:/ / www.eea.europa.eu/soer/2015/global/action-download-pdf (accessed on 1 August 2021).

4. Oerke, E.-C. Crop losses to pests. J. Agric. Sci. 2006, 144, 31-43. [CrossRef]

5. Balaško, K.M.; Mikac, K.M.; Bažok, R.; Lemic, D. Modern Techniques in Colorado Potato Beetle (Leptinotarsa decemlineata Say) Control and Resistance Management: History Review and Future Perspectives. Insects 2020, 11, 581. [CrossRef]

6. Oberemok, V.V.; Laikova, K.V.; Gninenko, Y.I.; Zaitsev, A.S.; Nyadar, P.M.; Adeyemi, T.A. A short history of insecticides. J. Plant Prot. Res. 2015, 55, 221-226. [CrossRef]

7. Casida, J.E.; Durkin, K.A. Anticholinesterase insecticide retrospective. Chem.-Biol. Interact. 2013, 203, 221-225. [CrossRef] [PubMed]

8. Gupta, R.C. Carbamate Pesticides. In Encyclopedia of Toxicology, 3rd ed.; Wexler, P., Ed.; Elsevier Science Publishers: Amsterdam, The Netherlands, 2014; pp. 661-664.

9. Le Goff, G.; Giraudo, M. Effects of pesticides on the environment and insecticide resistance. In Olfactory Concepts of Insect Control-Alternative to Insecticides; Picimbon, J.F., Ed.; Springer: Cham, Switzerland, 2019; pp. 51-78.

10. Kaneko, H. Pyrethroid chemistry and metabolism. In Hayes' Handbook of Pesticide Toxicology, 3rd ed.; Krieger, R., Ed.; Academic Press: Amsterdam, The Netherlands, 2010; pp. 1635-1663. 
11. Soderlund, D.M. Toxicology and mode of action of pyrethroid insecticides. In Hayes' Handbook of Pesticide Toxicology, 3rd ed.; Krieger, R., Ed.; Academic Press: Amsterdam, The Netherlands, 2010; pp. 1665-1686.

12. Insecticide Resistance Committee (IRAC). Available online: https://irac-online.org/documents/moa-classification/ (accessed on 15 July 2021).

13. Satelle, D.B.; Cordova, D.; Cheek, T.R. Insect ryanodine receptors: Molecular targets for novel pest control chemicals. Rev. Invert. Neurosci. 2008, 8, 107-119. [CrossRef]

14. Ebbinghaus-Kintscher, U.; Luemmen, P.; Lobitz, N.; Schulte, T.; Funke, C.; Fischer, R.; Masaki, T.; Yasokawa, N.; Tohnishi, M. Phthalic acid diamides activate ryanodine-sensitive $\mathrm{Ca}^{2+}$ release channels in insects. Cell Calcium 2006, 39, 21-33. [CrossRef] [PubMed]

15. Kadala, A.; Charreton, M.; Collet, C. Flubendiamide, the first phthalic acid diamide insecticide, impairs neuronal calcium signalling in the honey bee's antennae. J. Insect Physiol. 2020, 125, 104086-104093. [CrossRef] [PubMed]

16. Buszewski, B.; Bukowska, M.; Ligor, M.; Staneczko-Baranowska, I. A holistic study of neonicotinoids neuroactive insecticidesproperties, applications, occurrence, and analysis. Environ. Sci. Pollut. Res. Int. 2019, 26, 34723-34740. [CrossRef]

17. Chang, H.Y.; Daugherty, L.; Mitchell, A. Bee afraid, bee very afraid-Neonicotinoids and the nAChRs family. InterPro Protein Focus 2013, 25, 1-8.

18. Bonmatin, J.M.; Giorio, C.; Girolami, V.; Goulson, D.; Kreutzweiser, D.P.; Krupke, C.; Liess, M.; Long, E.; Marzaro, M.; Mitchell, E.A.D.; et al. Environmental fate and exposure; neonicotinoids and fipronil. Environ. Sci. Pollut. Res. 2015, 22, 35-67. [CrossRef]

19. European Commision Website for Food Safety. Available online: https:/ / ec.europa.eu/food/plants/pesticides/approval-activesubstances/renewal-approval/neonicotinoids_en (accessed on 21 July 2021).

20. Peter, J.V.; Sudarsan, T.I.; Moran, J.L. Clinical features of organophosphate poisoning: A review of different classification systems and approaches. Indian J. Crit. Care Med. 2014, 18, 735-745. [CrossRef]

21. Jenson, L.; Anderson, T.D.; Bloomquist, J.R. Insect Voltage-gated chloride channels as a possible insecticide target site. In Discovery and Synthesis of Crop Protection Products; Maienfisch, P., Stevenson, T.M., Eds.; American Chemical Society: Washington DC, USA, 2015; pp. 447-454.

22. Bloomquist, J.R. GABA and glutamate receptors as biochemical sites for insecticide action. In Biochemical Sites of Insecticide Action and Resistance; Ishaaya, I., Ed.; Springer: Berlin/Heidelberg, Germany, 2001; pp. 17-41.

23. Dong, K. Insect sodium channels and insecticide resistance. Invert. Neurosci. 2007, 7, 17-30. [CrossRef]

24. World Health Organization (WHO). Pesticide Evaluation Scheme, Vector Ecology and Management. Available online: http:/ / apps.who.int/iris/bitstream/handle/10665/44305/9789241599276_eng.pdf;jsessionid=5BEC372017196B11B48CED6 AF3B1289E? sequence=1 (accessed on 14 July 2021).

25. Elliott, M. Chemicals in insect control. In Pyrethrum Flowers: Production, Chemistry, Toxicology, and Uses; Casida, J.E., Quistad, G.B., Eds.; Oxford University Press: New York, NY, USA, 1995; pp. 3-31.

26. Nasuti, C.; Cantalamessa, F.; Falcioni, G.; Gabbianelli, R. Different effects of Type I and Type II pyrethroids on erythrocyte plasma membrane properties and enzymatic activity in rats. Toxicology 2003, 191, 233-244. [CrossRef]

27. Kurihara, N.; Miyamot, J.; Paulson, G.D.; Zeeh, B.; Skidmore, M.W.; Hollingworth, R.M.; Kuiper, H.A. Chirality in synthetic agrochemicals: Bioactivity and safety consideration. Pure Appl. Chem. 1997, 69, 2007-2025. [CrossRef]

28. Bradberry, S.M.; Cage, S.A.; Proudfoot, A.T.; Vale, J.A. Poisoning due to pyrethroids. Toxicol. Rev. 2005, 24, 93-106. [CrossRef] [PubMed]

29. Chrustek, A.; Hołyńska-Iwan, I.; Dziembowska, I.; Bogusiewicz, J.; Wróblewski, M.; Cwynar, A.; Olszewska-Słonina, D. Current research on the safety of pyrethroids used as insecticides. Medicina 2018, 54, 61. [CrossRef]

30. Cárcamo, J.G.; Aguilar, M.N.; Carreño, C.F.; Vera, T.; Arias-Darraz, L.; Figueroa, J.E.; Romero, A.P.; Alvarez, M.; Yañez, A.J Consecutive emamectin benzoate and deltamethrin treatments affect the expressions and activities of detoxification enzymes in the rainbow trout (Oncorhynchus mykiss) Comp. Biochem. Physiol. C Toxicol. Pharmacol. 2017, 191, 129-137. [CrossRef] [PubMed]

31. Burridge, L.E.; Haya, K. Lethality of pyrethrins to larvae and postlarvae of the American lobster (Homarus americanus). Ecotoxicol. Environ. Saf. 1997, 38, 150-154. [CrossRef]

32. Lidova, J.; Stara, A.; Kouba, A.; Velisek, J. The effects of cypermethrin on oxidative stress and antioxidant biomarkers in marbled crayfish (Procambarus fallax f. virginalis). Neuro Endocrinol. Lett. 2016, 37 (Suppl. 1), 53-59. [PubMed]

33. Lutnicka, H.; Kozińska, A. Pyrethroids as a predisposing factor in fish diseases. Ochr. Środ. Zasobów Nat. 2009, 41, $285-292$.

34. Wang, Y.; Lv, L.; Yu, Y.; Yang, G.; Xu, Z.; Wang, Q.; Cai, L. Single and joint toxic effects of five selected pesticides on the early life stages of zebrafish (Denio renio). Chemosphere 2017, 170, 61-67. [CrossRef]

35. Miyamoto, J.; Kaneko, H.; Tsuji, R.; Okuno, Y. Pyrethroids, nerve poisons: How their risks to human health should be assessed. Toxicol. Lett. 1995, 82-83, 933-940. [CrossRef]

36. Scollon, E.J.; Starr, J.M.; Godin, S.J.; DeVito, M.J.; Hughes, M.F. In vitro metabolism of pyrethroid pesticides by rat and human hepatic microsomes and cytochrome P450 isoforms. Drug Metab. Dispos. 2009, 37, 221-228. [CrossRef]

37. Damalas, C.A.; Eleftherohotinos, I.G. Pesticide Exposure, Safety Issues, and Risk Assessment Indicators. Int. J. Environ. Res. Public Health 2011, 8, 1402-1419. [CrossRef]

38. Glorennec, P.; Serrano, T.; Fravallo, M.; Warembourg, C.; Monfort, C.; Cordier, S.; Viel, J.; Le Gléau, F.; Le Bot, B.; Chevrier, C. Determinants of children's exposure to pyrethroid insecticides in western France. Environ. Int. 2017, 104, 76-82. [CrossRef] 
39. Del Prado-Lu, J.L. Insecticide residues in soil, water, and eggplant fruits and farmers' health effects due to exposure to pesticides. Environ. Health Prev. Med. 2015, 20, 53-62. [CrossRef]

40. Shafer, T.J.; Meyer, D.A.; Crofton, K.M. Developmental neurotoxicity of pyrethroid insecticides: Critical review and future research needs. Environ. Health Perspect. 2005, 113, 123-136. [CrossRef] [PubMed]

41. Nasuti, C.; Carloni, M.; Fedeli, D.; Gabbianelli, R.; Di Stefano, A.; Serafina, C.; Silva, I.; Dominques, V.; Ciccocioppo, R. Effects of early life permethrin exposure on spatial working memory and on monoamine levels in different brain areas of pre-senescent rats. Toxicology 2013, 303, 162-168. [CrossRef] [PubMed]

42. Nasuti, C.; Fattoretti, P.; Carloni, M.; Fedeli, D.; Ubaldi, M.; Ciccocioppo, R.; Gabbianelli, R. Neonatal exposure to permethrin pesticide causes lifelong fear and spatial learning deficits and alters hippocampal morphology of synapses. J. Neurodev. Dis. 2014, 6, 7. [CrossRef]

43. Outhlote, Y.; Bouchard, M. Urinary metabolities of organophosphate and pyrethroid pesticides and behavioral problems in Canadian children. Environ. Health Perspect. 2013, 121, 1378-1384.

44. Viel, J.F.; Warembourg, C.; Le Mauer-Idrissi, G.; Lacroix, A.; Limon, G.; Rouget, F.; Monfort, C.; Durand, G.; Cordier, S.; Cherier, C. Pyrethroid insecticide exposure and cognitive developmental disabilities in children: The PELAGIE mother-child cohort. Environ. Int. 2015, 82, 69-75. [CrossRef] [PubMed]

45. Skolarczyk, J.; Pekar, J.; Nieradko-Iwanicka, B. Immune disorders induced by exposure to pyrethroid insecticides. Postepy Hig. Med. Dośw. 2017, 71, 446-453. [CrossRef]

46. Corcellas, C.; Feo, M.L.; Torres, J.P.; Malm, O.; Ocampo-Duque, W.; Eljarrat, E.; Barceló, D. Pyrethroids in human breast milk: Occurrence and nursing daily intake estimation. Environ. Int. 2014, 47, 17-22. [CrossRef] [PubMed]

47. Mauro, R.; Li, Z. Unique insights into the actions of CNS agents: Lessons from studies of Chlorpyrifos and other common pesticides. Cent. Nerv. Syst. Agents Med. Chem. 2007, 7, 183-199. [CrossRef]

48. Wylie, B.J.; Hauptman, M.; Woolf, A.D.; Goldman, R.H. Insect Repellants during Pregnancy in the Era of the Zika Virus. Obstet. Gynecol. 2016, 128, 1111-1115. [CrossRef] [PubMed]

49. Central Disease Control. CDC Zika Interim Response Plan. Available online: https://www.cdc.gov/zika/pdfs/zika-draftinterim-conus-plan.pdf (accessed on 2 July 2021).

50. Raghavan, M.; Fee, D.; Barkhaus, P.E. Generation and propagation of the action potential. Handb. Clin. Neurol. 2019, 160, 3-22.

51. Rinkevich, F.D.; Du, Y.; Dong, K. Diversity and convergence of sodium channel mutations involved in resistance to pyrethroids. Pestic. Biochem. Physiol. 2013, 106, 93-100. [CrossRef]

52. Lipkind, G.M.; Fozzard, H.A. KcsA crystal structure as framework for a molecular model of the $\mathrm{Na}^{+}$channel pore. Biochemistry 2000, 39, 8161-8170. [CrossRef]

53. Wang, J.; Ou, S.W.; Wang, Y.J. Distribution and function of voltage-gated sodium channels in the nervous system. Channels 2017, 11, 534-554. [CrossRef] [PubMed]

54. Costa, L.G. The neurotoxicity of organochlorine and pyrethroid pesticides. Handb. Clin. Neurol 2015, 131, 135-148. [PubMed]

55. Taylor-Wells, J.; Brooke, B.D.; Bermudez, I.; Jones, A.K. The neonicotinoid imidacloprid, and the pyrethroid deltamethrin, are antagonists of the insect Rdl GABA receptor. J. Neurochem. 2015, 135, 705-713. [CrossRef] [PubMed]

56. Jenson, L.J. Characterization of Neuronal Structure and Insecticide Target Site Expression in Spodoptera frugiperda (Sf21) and Anopheles gambiae (Sua1B) Insect Cells. Ph.D. Thesis, University of Florida, Gainesville, FL, USA, 2013.

57. Quintavalle, A. Voltage-gated calcium channels in honey bees: Physiological roles and potential targets for insecticides. BioSci. Master Rev. 2013, 1-11. Available online: http://biologie.ens-lyon.fr/ressources/bibliographies/m1-11-12-biosci-reviewsquintavalle-a-1c-m.xml (accessed on 2 July 2021).

58. Wakeling, E.N.; Neal, A.P.; Atchison, W.D. Pyrethroids and their effects on ion channels. In Pesticides-Advances in Chemical and Botanical Pesticides; Soundararajan, R.P., Ed.; IntechOpen: London, UK, 2012; pp. 39-66.

59. Hildebrand, M.E.; McRory, J.E.; Snutch, T.P.; Stea, A. Mammalian voltage-gated calcium channels are potently blocked by the pyrethroid insecticide allethrin. J. Pharmacol. Exp. Ther. 2004, 308, 805-813. [CrossRef] [PubMed]

60. Neal, A.P.; Yuan, Y.; Atchison, W. Allethrin differentially modulates voltage-gated calcium channel subtypes in rat PC12 cells. Toxicol. Sci. 2010, 116, 604-613. [CrossRef]

61. Soderlund, D.M.; Clark, J.M.; Sheets, L.P.; Mullin, L.S.; Piccirillo, V.J.; Sargent, D.; Stevens, J.T.; Weiner, M.L. Mechanisms of pyrethroid toxicity: Implications for cumulative risk assessment. Toxicology 2002, 171, 3-59. [CrossRef]

62. Forshaw, P.J.; Lister, T.; Ray, D.E. The role of voltage-gated chloride channels in type II pyrethroid insecticide poisoning. Toxicol. Appl. Pharmacol. 2000, 163, 1-8. [CrossRef]

63. Breckenridge, C.B.; Holden, L.; Sturgess, N.; Weiner, M.; Sheets, L.; Sargent, D.; Soderlund, D.M.; Choi, J.-S.; Symington, S.; Clark, J.M.; et al. Evidence for separate mechanism of toxicity for type I and type II pyrethroid insecticides. Neurotoxicology 2009, 30, S17-S31. [CrossRef]

64. Deglise, P.; Grunewald, B.; Gauthier, M. The insecticide imidacloprid is a partial agonist of the nicotinic receptor of honeybee Kenyon cells. Neurosci. Lett. 2002, 321, 13-16. [CrossRef]

65. Casagrande, R.A. The Colorado potato beetle: 125 years of mismanagement. Bull. Entomol. Soc. 1987, 33, 142-150. [CrossRef]

66. Alyokhin, A.; Mota-Sanchez, D.; Baker, M.; Snyder, W.E.; Menasha, S.; Whalon, M.; Dively, G.; Moarsi, W.F. Red Queen on a potato field: IPM vs. chemical dependency in Colorado potato beetle control. Pest Manag. Sci. 2015, 71, 343-356. [CrossRef] [PubMed] 
67. Alyokhin, A. Colorado potato beetle management on potatoes: Current challenges and future prospects. Fruit Veg. Cereal Sci. Biotechnol. 2009, 3, 10-19.

68. Hare, J.D. Ecology and management of the Colorado potato beetle. Annu. Rev. Entomol. 1990, 35, 81-100. [CrossRef]

69. Senanayake, D.; Ratcliffe, E.B.; Holliday, N.J. Oviposition and diapause behavior in Colorado potato beetle (Coleoptera: Chrysomelidae) populations from east central Minnesota and the valley of the Red River of the North. Environ. Entomol. 2000, 29, 1123-1132. [CrossRef]

70. Radcliffe, E.B.; Lagnaoui, A. Insect pests in potato. In Potato Biology and Biotechnology: Advances and Perspectives; Elsevier Science BV: Amsterdam, The Netherlands, 2007; pp. 543-567.

71. Alyokhin, A.; Choban, R. Maturity-dependent mortality of Colorado potato beetle eggs treated with novaluron. Am. J. Potato Res. 2010, 87, 557-560. [CrossRef]

72. Hsiao, H.T.H. Host specificity, seasonality and bionomics of Leptinotarsa beetles. In Biology of Chrysomelidae; Kluwer Academic Publishers: Dordrecht, The Netherlands, 1988; pp. 581-659.

73. Udalov, M.B.; Benkovskaya, G.V. Population genetics of the Colorado potato beetle: From genotype to phenotype. Russ. J. Genet. Appl. Res. 2011, 1, 321-333. [CrossRef]

74. Schoville, S.D.; Chen, Y.H.; Andersson, M.N.; Benoit, J.B.; Bhandari, A.; Bowsher, J.H.; Brevik, K.; Cappelle, K.; Chen, M.J.M.; Childers, A.K.; et al. A model species for agricultural pest genomics: The genome of the Colorado potato beetle, Leptinotarsa decemlineata (Coleoptera: Chrysomelidae). Sci. Rep. 2018, 8, 1931-1949. [CrossRef]

75. Alyokhin, A.; Vincent, C.; Giordanengo, P. Insect Pests of Potato: Global Perspectives on Biology and Management, 1st ed.; Accademic Press: Oxford, UK, 2013; pp. 77-96.

76. Shields, E.J.; Wyman, J.A. Effect of defoliation at specific growth stages on potato yields. J. Econ. Entomol. 1984, 77, 1194-1199. [CrossRef]

77. Maharijaya, A.; Vosman, B. Managing the Colorado potato beetle; the need for resistance breeding. Euphytica 2015, 204, 487-501. [CrossRef]

78. Margus, A.; Piiroinen, S.; Lehmann, P.; Tikka, S.; Karvanen, J.; Lindstorm, L. Sublethal pyrethroid insecticide exposure carries positive fitness effects over generations in a pest insect. Sci. Rep. 2019, 9, 11320-11330. [CrossRef]

79. Alyokhin, A.; Baker, M.; Mota-Sanchez, D.; Dively, G.; Grafius, E. Colorado potato beetle resistance to insecticides. Am. J. Potato Res. 2008, 85, 395-413. [CrossRef]

80. Bishop, B.A.; Grafius, E.J. Insecticide resistance in the Colorado potato beetle. In Chrysomelidae Biology; Jolivet, P., Cox, M.L., Eds.; SBP Academic Publishing: Amsterdam, The Netherlands, 1996; Volume 1, pp. 355-377.

81. Sladan, S.; Miroslav, K.; Ivan, S.; Snezana, J.; Petar, K.; Goran, T.; Jevdovic, R. Resistance of colorado potato beetle (Coleoptera: Chrysomelidae) to neonicotinoids, pyrethroids and nereistoxins in Serbia. Rom. Biotechnol. Lett. 2012, 17, 7599-7609.

82. Scott, I.M.; Tolman, J.H.; MacArthur, D.C. Insecticide resistance and cross-resistance development in Colorado potato beetle Leptinotarsa decemlineata Say (Coleoptera: Chrysomelidae) populations in Canada 2008-2011. Pest Manag. Sci. 2015, 71, 712-721. [CrossRef]

83. Whalon, M.; Mota-Sanchez, D.; Hollingworth, R.; Duynslager, L. Arthropod Pesticide Resistance Database. 2013. Available online: http:/ / www.pesticideresistance.com/ (accessed on 12 April 2021).

84. Rondon, S.I.; Feldman, M.; Thompson, A.; Oppedisano, T.; Shrestha, G. Identifying resistance to the Colorado potato beetle (Leptinotarsa decemlineata Say) in potato germplasm: Review update. Front. Agron. 2021, 3, 642189. [CrossRef]

85. Hemingway, J. The molecular basis of two contrasting metabolic mechanisms of insecticide resistance. Insect Biochem. Mol. Biol. 2000, 30, 1009-1015. [CrossRef]

86. Zichova, T.; Kocourek, F.; Salava, J.; Nadova, K.; Stara, J. Detection of organophosphate and pyrethroid resistance alleles in Czech Leptinotarsa decemlineata (Coleoptera: Chrysomelidae) populations by molecular methods. Pest Manag. Sci. 2010, 66, 853-860.

87. Kim, H.J.; Yoon, K.S.; Clark, J.M. Functional analysis of mutations in expressed acetylcholinesterase that result in azinphosmethyl and carbofuran resistance in Colorado potato beetle. Pestic. Biochem. Physiol. 2007, 88, 181-190. [CrossRef]

88. Zhu, K.Y.; Lee, S.H.; Clark, J.M. A point mutation of acetylcholinesterase associated with azinphosmethyl resistance and reduced fitness in Colorado potato beetle. Pestic. Biochem. Physiol. 1996, 55, 100-108. [CrossRef]

89. Williamson, M.S.; Martinez-Torres, D.; Hick, C.A.; Devonshire, A.L. Identification of mutations in the housefly para-type sodium channel gene associated with knockdown resistance $(k d r)$ to pyrethroid insecticides. Mol. Gen. Genet. 1996, 252, 51-60. [CrossRef]

90. Miyazaki, M.; Ohyama, K.; Dunlap, D.Y.; Matsumura, F. Cloning and sequencing of the paratype sodium channel gene from susceptible and kdr-resistant German cockroaches (Blattella germanica) and house fly (Musca domestica). Mol. Gen. Genet. 1996, 252, 61-68.

91. Dong, K. A single amino acid change in the para sodium channel protein is associated with knockdown-resistance (kdr) to pyrethroid insecticides in German cockroach. Insect Biochem. Mol. Biol. 1997, 27, 93-100. [CrossRef]

92. Martinez-Torres, D.; Chandre, F.; Williamson, M.S.; Darriet, F.; Berge, J.B.; Devonshire, A.L.; Guillet, P.; Pasteur, N.; Pauron, D. Molecular characterization of pyrethroid knockdown resistance (kdr) in the major malaria vector Anopheles gambiae s. s. Insect Mol. Biol. 1998, 7, 179-184. [CrossRef] [PubMed]

93. Martinez-Torres, D.; Foster, S.P.; Field, L.M.; Devonshire, A.L.; Williamson, M.S. A sodium channel point mutation is associated with resistance to DDT and pyrethroid insecticides in the peachpotato aphid, Myzus persicae (Sulzer) (Hemiptera: Aphididae). Insect Mol. Biol. 1999, 8, 339-346. [CrossRef] [PubMed] 
94. Zamojska, J.; Węgorek, P.; Mrowczynski, P. Changes in the Colorado potato beetle (Leptinotarsa decemlineata Say) susceptibility level to pyrethroids and the pest resistance mechanisms to deltamethrin. J. Plant Prot. Res. 2011, 3, 294-299. [CrossRef]

95. Rinkevich, F.D.; Su, C.; Lazo, T.A.; Hawthorne, D.J.; Tingey, W.M.; Naimov, S.; Scott, J.G. Multiple evolutionary origins of knockdown resistance $(k d r)$ in pyrethroid-resistant Colorado potato beetle, Leptinotarsa decemlineata. Pestic. Biochem. Physiol. 2012, 104, 192-200. [CrossRef]

96. Wegorek, P. Current status of resistance in Colorado potato beetle (Leptinotarsa decemlineata Say) to selected active substances of insecticides in Poland. J. Plant Prot. Res. 2005, 45, 309-319.

97. Clements, J.; Schoville, S.; Peterson, N.; Lan, Q.; Groves, R.L. Characterizing Molecular Mechanisms of Imidacloprid Resistance in Select Populations of Leptinotarsa decemlineata in the Central Sands Region of Wisconsin. PLoS ONE 2016, 11, e0147844. [CrossRef]

98. Kaplanoglu, E.; Chapman, P.; Scott, I.M.; Donly, C. Overexpression of a cytochrome P450 and a UDP-glycosyltransferase is associated with imidacloprid resistance in the Colorado potato beetle, Leptinotarsa decemlineata. Sci. Rep. 2017, 7, 1762. [CrossRef] [PubMed]

99. Sánchez-Bayo, F.; Tennekes, H.A.; Goka, K. Impact of Systemic Insecticides on Organisms and Ecosystems. In InsecticidesDevelopment of Safer and More Effective Technologies; Trdan, S., Ed.; IntechOpen: London, UK, 2013; pp. 1-45.

100. European Commission. Sustainable Use of Pesticides. Available online: https://www.eca.europa.eu/Lists/ECADocuments/SR2 0_05/SR_Pesticides_EN.pdf (accessed on 25 June 2021).

101. EUROSTAT. Available online: http:/ / appsso.eurostat.ec.europa.eu/nui/show.do?dataset=aei_fm_salpest09\&lang=en (accessed on 4 May 2021).

102. FAOSTAT. Available online: http:/ / www.fao.org/faostat/en/\#data/RP (accessed on 11 May 2021).

103. Huseth, A.S.; Frost, K.E.; Knuteson, D.L.; Wyman, J.A.; Groves, R.L. Effects of landscape composition and rotation distance on Leptinotarsa decemlineata (Coleoptera: Chrysomelidae) abundance in cultivated potato. Environ. Entomol. 2012, 41, 1553-1564 [CrossRef]

104. Stoner, K.A. Influence of mulches on the colonization by adults and survival of larvae of the Colorado potato beetle in eggplant. J. Entomol. Sci. 1997, 32, 7-16. [CrossRef]

105. Hoy, C.W.; Vaught, T.T.; East, D.A. Increasing the effectiveness of spring trap crops for Leptinotarsa decemlineata. Entomol. Exp. Appl. 2000, 96, 193-204. [CrossRef]

106. Yasar, B.; Gungor, M.A. Determination of life table and biology of Colorado potato beetle, Leptinotarsa decemlineata Say (Coleoptera: Chrysomelidae), feeding on five different potato varieties in Turkey. Appl. Entomol. Zool. 2005, 40, 589-596. [CrossRef]

107. Thompson, A.L.; Farnsworth, B.L.; Gudmestad, N.C.; Secor, G.A.; Preston, D.A.; Sowokinos, J.R.; Glznn, M.; Hatterman-Valenti, H. Dakota Diamond: An exceptionally high yielding, cold chipping potato cultivar with long-term storage potential. Am. J. Pot. Res. 2008, 85, 171-182. [CrossRef]

108. Göldel, B.; Lemic, D.; Bažok, R. Alternatives to Synthetic Insecticides in the Control of the Colorado Potato Beetle (Leptinotarsa decemlineata Say) and Their Environmental Benefits. Agriculture 2020, 10, 611. [CrossRef]

109. Sablon, L.; Haubruge, E.; Verhegeen, F.J. Consumption of immature stages of Colorado potato beetle by Chrysoperla carnea (Neuroptera: Chrysopidae) larvae in the laboratory. Am. J. Pot. Res. 2013, 90, 51-57. [CrossRef]

110. Moore, J. Sweeping fields controls some pests. Am. Veg. Grow. 1990, 1, 10-11.

111. Laguë, C.; Khelifi, M.; Gill, J.; Lacasse, B. Pneumatic and thermal control of Colorado potato beetle. Can. Agric. Eng. 1999, 41, 53-58.

112. Rondon, S.I.; Pantoja, A.; Hagerty, A.; Horneck, D.A. Ground beetle (Coleoptera: Carabidae) populations in commercial organic and conventional potato production. Fla. Entomol. 2013, 96, 1492-1499. [CrossRef]

113. Wraight, S.P.; Ramos, M.E. Delayed efficacy of Bacillus thuringensis foliar spray applications against Colorado potato beetle: Impacts of number and timing of applications on larval and next generation adult population. Biol. Control 2015, 83, 51-67. [CrossRef]

114. Öztürk, H.E.; Güven, Ö.; Karaca, I. Effects of some bioinsecticides and entomopathogenic fungi on Colorado potato beetle (Leptinotarsa decemlineata L.). Commun. Agric. Appl. Biol. Sci. 2015, 80, 205-211.

115. Scott, I.M.; Jensen, H.; Scott, J.G.; Isman, M.B.; Arnason, J.T.; Philogène, B.J. Botanical insecticides for controlling agricultural pests: Piperamides and the Colorado Potato Beetle Leptinotarsa decemlineata say (Coleoptera: Chrysomelidae). Arch. Insect Biochem. Physiol. 2003, 54, 212-225. [CrossRef] [PubMed]

116. Alvarez, J.M.; Srinivasan, R.; Cervantes, F.A. Occurrence of the carabid beetle, Pterostichus melanarius (Illiger), in potato ecosystems of Idaho and its predatory potential on the Colorado potato beetle and aphids. Am. J. Potato Res. 2013, 90, 83-92. [CrossRef]

117. Lopez, E.R.; Ferro, D.N.; Van Driesche, R.G. Direct measurement of host and parasitoid recruitment for assessment of total losses due to parasitism in the Colorado potato beetle Leptinotarsa decemlineata (Say) (Coleoptera: Chrysomelidae) and Myiopharus doryphorae (Riley) (Diptera: Tach). Biol. Control 1993, 3, 85-92. [CrossRef]

118. Lopez, E.R.; Roth, L.C.; Ferro, D.N.; Hosmer, D.; Mafra-Neto, A. Behavioral ecology of Myiopharus doryphorae (Riley) and M. aberrans (Townsend), tachinid parasitoids of the Colorado potato beetle. J. Insect Behav. 1997, 10, 49-78. [CrossRef]

119. Hough-Goldstein, J.; McPherson, D. Comparison of Perillus bioculatus and Podisus maculiventris (Hemiptera: Pentatomidae) as potential control agents of the Colorado potato beetle (Coleoptera: Chrysomelidae). J. Econ. Entomol. 1996, 89, 1116-1123. [CrossRef]

120. Chang, G.C.; Snyder, W.E. The relationship between predator density, community composition, and field predation of Colorado potato beetle eggs. Biol. Control 2004, 31, 453-461. [CrossRef] 
121. Koss, A.M.; Chang, G.C.; Snyder, W.E. Predation of green peach aphids by generalist predators in the presence of alternative, Colorado potato beetle egg prey. Biol. Control 2004, 31, 237-244. [CrossRef]

122. Koss, A.M.; Jensen, A.S.; Schreiber, A.; Pike, K.S. Comparison of predator and pest communities in Washington potato fields treated with broad-spectrum, selective, or organic insecticides. Environ. Entomol. 2005, 34, 87-95. [CrossRef]

123. Ertürk, O.; Yaman, M.; Aslam, I. Effects of four Bacillus spp. of soil origin on the Colorado potato beetle Leptinotarsa decemlineata (Say). Entomol. Res. 2008, 38, 135-138. [CrossRef]

124. Gassmann, A.J.; Carrière, Y.; Tabashnik, B.E. Fitness costs of insect resistance to Bacillus thuringiensis. Annu. Rev. Entomol. 2009, 54, 147-163. [CrossRef]

125. Walker, K.; Mendelsohn, M.; Matten, S.; Alphin, M.; Alven, D. The role of microbial Bt products in US crop protection. J. New. Seeds 2003, 5, 31-51. [CrossRef]

126. Ghassemi-Kahrizeh, A.; Aramideh, S. Sub-lethal effects of Bacillus thuringiensis Berliner on larvae of Colorado potato beetle, Leptinotarsa decemlineata (say) (Coleoptera: Chrysomelidae). Arch. Phytopathol. Pflanzenschutz 2015, 48, 259-267. [CrossRef]

127. Cingel, A.; Savić, J.; Lazarević, J.; Ćosić, T.; Raspor, M.; Smigocki, A.; Ninković, S. Extraordinary adaptive plasticity of Colorado potato beetle: "Ten-Striped Spearman" in the era of biotechnological warfare. Int. J. Mol. Sci. 2016, 17, 1538. [CrossRef] [PubMed]

128. Ma, M.; He, W.; Xu, S.; Xu, L.; Zhang, J. RNA interference in Colorado potato beetle (Leptinotarsa decemlineata): A potential strategy for pest control. J. Integr. Agric. 2020, 19, 428-437. [CrossRef]

129. Gui, S.; Taning, C.N.T.; Wei, D.; Smagghe, G. First report on CRISPR/Cas9-targeted mutagenesis in the Colorado potato beetle, Leptinotarsa decemlineata. J. Insect Physiol. 2020, 121, 104013. [CrossRef] [PubMed]

130. Pelletier, Y. Level and genetic variability of resistance to the Colorado potato beetle (Leptinotarsa decemlineata (Say)) in wild Solanum species. Am. J. Potato Res. 2007, 84, 143-148. [CrossRef]

131. Mărgineanu, A.-M.; Erdelyi-Molnar, I.; Rakosy-Tican, E. Trichomes types analysis and their density in parental species Solanum tuberosum and S. chacoense and their derived somatic hybrids. An. Ştiinţifice Univ. Al. I. Cuza Iaşi s. II a. Biol. Veg. 2014, 60, 33-42.

132. Cruceriu, D.; Erdelyi-Molnar, I.; Diaconeasa, Z.; Măgineanu, A.-M.; Aurori, A.; Rakosy-Tican, E. Comparative characterization of somatic hybrids of Solanum bulbocastanum + S. tuberosum cv. 'Rasant' with their parents in relation to biochemical responses to wound stress and trichome composition. Studia UBB Chem. 2020, 65, 133-148. [CrossRef]

133. Thieme, R.; Rakosy-Tican, E. Somatic cell genetics and its application in potato breeding. In The Potato Genome; Chakrabarti, S.K., Xie, C., Tiwari, J.K., Eds.; Springer International Publishing AG: Cham, Switzerland, 2017; pp. 217-269.

134. Thieme, R.; Rakosy-Tican, E.; Gavrilenko, T.; Antonova, O.; Schubert, J.; Nachtigall, M.; Heimbach, U.; Thieme, T. Novel somatic hybrids (Solanum tuberosum L. + Solanum tarnii) and their fertile BC1 progenies express extreme resistance to potato virus $\mathrm{Y}$ and late blight. Theor Appl. Genet. 2008, 116, 691-700. [CrossRef]

135. Thieme, R.; Rakosy-Tican, E.; Nachtigall, M.; Schubert, J.; Hammann, T.; Antonova, O.; Gavrilenko, T.; Heimbach, U.; Thieme, T. Characterization of multiple resistance traits of somatic hybrids between Solanum cardiophyllum Lindl. and two commercial potato cultivars. Plant Cell Rep. 2010, 29, 1187-1201. [CrossRef] [PubMed]

136. Molnár, I.; Besenyei, E.; Thieme, R.; Thieme, T.; Aurori, A.; Baricz, A.; Banciu, H.L.; Rakosy-Tican, E. Mismatch repair deficiency increases the transfer of antibiosis and antixenosis properties against Colorado potato beetle in somatic hybrids of Solanum tuberosum + S. chacoense. Pest Manag. Sci. 2016, 73, 1428-1437. [CrossRef] [PubMed]

137. Rakosy-Tican, E.; Besenyei, E.; Molnár, I.; Thieme, R.; Hartung, F.; Sprink, T.; Antonova, O.; Famelaer, I.; Angenon, G.; Aurori, A. New phenotypes of potato co-induced by mismatch repair deficiency and somatic hybridization. Front. Plant Sci. 2019, 10, 1-18. [CrossRef] [PubMed] 